\title{
Analisis Pengukuran Kinerja Reksa Dana Saham Dengan Metode Sharpe, Treynor, Dan Jensen Di Bursa Efek Indonesia
}

\author{
Tina Sulistiyani, S.E., M.M. \\ Program Studi Manajemen, Fakultas Ekonomi dan Bisnis Universitas Ahmad Dahlan \\ tina.sulistiyani@mgm.uad.ac.id
}

\begin{abstract}
ABSTRAK
Penelitian ini bertujuan untuk mengetahui kinerja reksa dana saham berdasarkan metode sharpe, Treynor, dan Jensen. Selain itu, penelitian ini memiliki tujuan mengetahui reksa dana mana yang memiliki kinerja outperform dan underperform terhadap IHSG. Periode penelitian yang digunakan adalah tahun 2013-2016. Penelitian ini merupakan penelitian kuantitatif deskriptif. Populasi penelitian adalah seluruh reksa dana saham yang terdaftar di Bursa Efek Indonesia Periode 2013-2016. Pemilihan sampel ditentukan dengan teknik purposive sampling dengan kriteria saham yang yang dijadikan sampel adalah saham non-syariah dan aktif selama periode 2013-2016, sehingga diperoleh sampel sebanyak 48 reksa dana saham. Hasil penelitian berdasarkan metode Sharpe tahun 2013, 4 reksa dana saham berkinerja positif dan 44 negatif. Tahun 2014, 47 positif dan 1 negatif, tahun 2015, tidak ada reksa dana yang berkinerja positif dan 48 reksa dana saham negatif, Sedangkan untuk tahun 2016, 48 reksa dana saham memiliki kinerja positif dan tidak ada reksa dana yang berkinerja negatif. Untuk perbandingan dengan benchmark IHSG padaTahun 2013, 7 reksa dana saham outperform dan 41 underperform. Tahun 2014, 42 reksa dana saham outperform dan 6 underperform. Tahun 2015, 1 reksa dana saham outperform dan 4 underperform. Pada Tahun 2016 hasil kembali menunjukkan yang baik dengan bukti bahwa hanya ada 8 reksa dana saham yang underperform dan 38 reksa dana saham lainnya mampu outperform terhadapat bencmark IHSG.Berdasarkan metode Treynor tahun 2013, 44 reksa dana saham berkinerja positif dan 4 negatif. Tahun 2014, 47 positif dan 1 negatif, tahun 2015, tidak ada reksa dana yang berkinerja positif dan 48 reksa dana saham negatif. Pada tahun 2016 terdapat 37 reksa dana saham yang mempunyai kinerja positif dan hanya ada 11 reksa danayang mempunyai hasil negatif. Untuk perbandingan dengan benchmark IHSG pada Tahun 2013, 44 reksa dana saham outperform dan 4 underperform. Tahun 2014, 43 reksa dana saham outperform dan 5 underperform. Tahun 2015, tidak ada reksa dana saham outperform dan 48 underperform, Pada tahun 2016 reksa dana kembali menunjukkan hasil yang baik terbukti dengan 25 reksa dana saham yang mampu outperform terhadapat bencmark IHSG dan 23 lainnya memiliki kinerja underperform. Berdasarkan metode Jensen tahun 2013, 2 reksa dana shaam berkinerja positif dan 46 negatif. Tahun 2014, 47 positif dan 1 negatif, tahun 2015, tidak ada reksa dana yang berkinerja positif dan 48 reksa dana saham negatif. Pada tahun 2016, 37 reksa dana saham memiliki kinerja positif dan 11 reksa dana saham memiliki kinerja negatif. Untuk perbandingan dengan benchmark IHSG pada Tahun 2013, 47 reksa dana saham outperform dan 1 underperform. Tahun 2014, 47 reksa dana saham outperform dan 1 underperform. Tahun 2015, 48 reksa dana saham outperform dan tidak ada reksa dana saham yang mempunyai kinerja underperform, pada tahun 2016 dengan hasil Sebanyak 48 reksa dana saham underperform terhadap benchmark dan tidak ada reksa dana saham yang berkinerja outperform terhadap benchmark IHSG.
\end{abstract}

Kata Kunci: Reksa dana saham, Metode Sharpe, Treynor, Jensen, Benchmark, outperform, underperform. 


\section{PENDAHULUAN}

Investasi tidak langsung melalui investment companies (Reksa Dana) sebagai intermediasi keuangan sedang berkembang pesat. Reksa Dana saham merupakan jenis Reksa Dana yang paling banyak diminati, suatu wadah yang digunakan untuk menghimpun dana investor yang selanjutnya diinvestasikan dalam portofolio berbagai jenis saham oleh manajer investasi. Perkembangan pesat ini ditinjau dari keunggulan Reksa Dana saham terutama, skala ekonomis dalam akses ke pasar saham dan diversifikasi investasi, manajer investasi yang profesional, dan return yang paling tinggi dibandingkan dengan Reksa Dana jenis lain (Wibowo, 2005). Sehingga, Reksa Dana saham merupakan sebuah solusi bagi masyarakat yang tidak memiliki pengetahuan tentang analisis investasi tetapi ingin berinvestasi pada pasar saham dengan dana terjangkau. Meskipun begitu investasi di Reksa Dana saham bukan berarti tidak berisiko, masih banyak investor yang belum mengetahui hubungan antara return dan risiko, kebanyakan dari mereka hanya membentuk portofolio Reksa Dana secara acak tanpa melakukan analisis terlebih dahulu. Mereka terlalu percaya pada manajer investasi yang mengelola dana mereka. Diperlukan analisis pengukuran untuk mengetahui baik atau tidaknya suatu Reksa Dana saham sehingga investor dapat selalu memperoleh return yang optimal dengan risiko terendah. Analisis pengukuran yang digunakan adalah analisis pengukuran kinerja Reksa Dana saham dengan mengkombinasikan antara return dan risiko yang biasa disebut dengan istilah RiskAdjusted Return. Selain itu, kinerja Reksa Dana saham juga dibandingkan dengan kinerja benchmark (IHSG) agar dapat diketahui Reksa Dana yang mampu outperform maupun underperform. Reksa dana pada dasarnya dapat dibagi menjadi beberapa kategori berdasarkan tingkat risikonya, diantaranya : pertama, reksa dana dengan risiko rendah seperti reksa dana Pasar Uang; kedua, reksa dana risiko rendah hingga menengah seperti reksa dana pendapatan tetap, reksa dana terproteksi, reksa dana campuran dengan alokasi saham tertentu; ketiga, reksa dana risiko mengah hingga tinggi seperti reksa dana campuran dengan orientasi saham yang cukup besar; keempat, reksa dana dengan risiko tinggi seperti reksa dana saham. Makin besar potensi risiko suatu reksa dana makin besar potensi imbal hasil keuntungan yang dapat diharapkan (pratomo 2014). Reksa dana merupakan salah satu sarana berinvestasi yang menawarkan keuntungan tinggi. Investor dapat memilih alokasi dananya berdasarkan instrumen pasar modal sesuai dengan tingkat risiko dan return yang diinginkan. Semakin tinggi keuntungan yang ditawarkan, semakin besar juga potensi kerugiannya (high risk high return). Para investor harus memahami dengan baik jenis-jenis reksa dana karena menawarkan keuntungan beserta potensi kerugian yang berbeda-beda. Berdasarkan situs resmi dari Otorita Jasa Keuangan (ojk.go.id), total komposisi NAB Reksa Dana Saham hingga bulan Februari 2016 sebesar 106,48 triliun atau 36,95\% dari total reksa dana yang ada. Data tersebut menunjukkan bahwa hampir sebagian dari instrumen Reksa Dana yang ada merupakan jenis reksa dana saham.

Berdasarkan pembatasan masalah di atas maka, perumusan masalah dalam penelitian ini adalah sebagai berikut :

1. Bagaimana kinerja Reksa Dana saham berdasarkan Metode Sharpe, Treynor, dan Jensen periode 2013-2016?

2. Bagaimana kinerja Reksa Dana saham dibandingkan dengan kinerja benchmark (IHSG) periode 2013-2016?

\section{KAJIAN PUSTAKA}

\section{Investasi}

Sunariyah (2005) berpendapat bahwa investasi adalah tindakan menanamkan sebagian modal yang dimiliki dan biasanya berjangka waktu panjang dengan harapan mendapatkan keuntungan 
dimasa yang akan datang. Ada tiga hal utama yang menjadikan perlunya melakukan investasi (Pratomo, 2004): a. Adanya kebutuhan di masa mendatang yang belum mampu dipenuhi sehingga menginvestasikan aset yang dimiliki dan berharap mendapatkan keuntungan di masa mendatang. b. Adanya keinginan untuk menambah nilai aset serta kebutuhan untuk melindungi nilai aset yang sudah dimiliki saat ini. c. Adanya inflasi yang membuat harga-harga cenderung naik sehingga akan mempengaruhi pengeluaran sehari-hari. Kegiatan investasi pada dasarnya dibedakan menjaadi dua bentuk, yaitu dengan menginvestasikan sejumlah data dalam bentul aset riil (real assets) maupun dalam aset finansial ( financial assets). Investasi pada aset-aset finansial dilakukan dipasar uang, misalnya berupa sertifikat deposito, commercial paper, surat berharga pasar uang, dan lainnya. Investasi dapat dilakukan di pasar modal, misalnya berupa saham, obligasi, opsi, dan lain-lain. Investasi pada aset-aset riil dapat berbentuk pembelian aset produktif, pendirian pabrik, pembukaan pertambangan, pembukaan perkebunan dan lainnya. (Halim, 2005).

\section{Pasar Modal}

Tandelilin (2001) menjelaskan bahwa pasar modal adalah pertemuan antara pihak yang memiliki kelebihan dana dengan pihak yang membutuhkan dana dengan memperjualbelikan sekuritas. Dengan demikian, pasar modal juga bisa diartikan sebagai pasar untuk memperjualbelikan sekuritas yang umumnya memiliki umur lebih dari satu tahun, seperti saham dan obligasi. Sedangkan tempat dimana terjadinya jual beli sekuritas disebut dengan Bursa Efek. Di indonesia ada dua bursa efek yaitu Bursa Efek Jakarta (BEJ) dan Bursa Efek Surabaya (BES), namun sejak 2007 keduanya digabung menjadi Bursa Efek Indonesia (BEI).

Instrumen Pasar modal Terdapat beberapa instrumen penting yang berada di dalam pasar modal. Instrumen tersebut memiliki karakteristik serta keuntungan beserta kerugian yang berbeda.

1) Saham Saham merupakan surat bukti kepemilikan atas aset-aset perusahaan yang menerbitkan saham. Menurut Jogiyanto (2013) saham terdiri dari tiga jenis yaitu saham biasa (common stock), saham preferen (preffered stock), dan saham treasuri Obligasi Menurut Jogiyanto (2013).

2) obligasi merupakan utang jangka panjang yang akan dibayarkan kembali pada saat jatuh tempo dengan bunga yang tetap jika ada. Bunga tersebut bersifat tetap sehingga dalam reksa dana jenis instrumen ini sering dikenal sebagai reksa dana pendapatan tetap. Jenis ini memberikan keuntungan yang relatif kecil namun memiliki potensi yang kecil pula. Meskipun demikian, obligasi bukan tanpa risiko, karena bisa saja obligasi tersebut tak terbayar kembali akibat kegagalan penerbitnya dalam memenuhi kewajibannya.

3) Reksa Dana Menurut Tandelilin (2001) Reksa Dana (mutual fund) adalah suatu jenis instrumen investasi yang juga disediakan di pasar modal Indonesia disamping saham, obligasi,dan sebagainya. Perusahaan Reksa Dana akan menghimpun dana investor untuk kemudian diinvestasikan dalam bentuk portofolio yang dibentuk oleh manajer investasi.

4) Instrumen Derivatif (Opsi dan Futures) Instrumen derivatif merupakan sekuritas yang nilainya merupakan turunan dari suatu sekuritas lain, sehingga nilai instrumen derivatif sangat tergantung dari harga sekuritas lain yang ditetapkan sebagai patokan. Ada beberapa jenis instrumen derivative, diantaranya waran, bukti right (righti issue), opsi dan futures.

\section{Return}

Return merupakan imbalan yang di terima investor dari suatu investasi. Halim (2001) berpendapat bahwa return dibedakan menjadi dua, yaitu return realisasi (actual return) dan return ekspektasi ( expected return). Harapan keuntungan di masa yang akan datang tersebut 
merupakan kompensasi atas waktu dan risiko yang terkait dengan investasi yang dilakukan. Dalam konteks investasi, harapan keuntungan tersebut sering juga disebut sebagai return. Sumber-sumber return investasi terdiri dari dua komponen utama, yaitu yield dan capital gain (loss). Yield merupakan komponen return yang mencerminkan kas atau pendapatan yang diperoleh secara periodik dari suatu investasi. Sedangkan, capital gain (loss) merupakan kenaikan (penurunan) harga yang memberikan keuntungan (kerugian) bagi investor. Dengan kata lain, capital gain (loss) bisa diartikan sebagai perubahan harga sekuritas.

\section{Reksa Dana}

Reksa Dana adalah wadah yang dipergunakan untuk menghimpun dana dari masyarakat pemodal, untuk selanjutnya diinvestasikan oleh manajer investasi dalam Portofolio Efek. Keuntungan yang diperoleh berupa kenaikan nilai investasi masyarakat pemodal seiring dengan berjalannya waktu periode investasi (Manurung, 2008). Undang-undang Nomor 8 tahun 1995, Reksa Dana adalah wadah yang digunakan untuk menghimpun dana dari masyarakat pemodal untuk selanjutnya diinvestasikan dalam portofolio efek oleh Manajer Investasi. a. NAB Reksa Dana NAB merupakan kepanjangan dari Nilai Aktiva Bersih. NAB menunjukkan berapa besar nilai aset yang dikelola dalam suatu Reksa Dana. Istilah untuk menyatakan harga suatu Reksa Dana yaitu NAB/UP (Nilai Aktiva Bersih per Unit Penyertaan). Kata NAB mengadaptasi istilah dari Amerika yaitu Net Asset Value (NAV). Istilah ini sering digunakan dalam publikasi, laporan atau riset yang menggunakan bahasa Inggris sebagai bahasa pengantar. NAB yang sebenarnya menunjukkan besarnya jumlah dana yang dikelola sudah dianggap sebagai harga Reksa Dana meski kurang tepat. Untuk membedakan harga dengan jumlah aset yang dikelola, digunakan istilah AUM (Asset Under Management) atau jumlah dana kelolaan dalam bahasa Indonesia.

\section{METODE PENELITIAN}

\section{Populasi, Sampel dan Teknik Sampel}

Populasi dalam penelitian ini sebanyak 232 Reksa Dana saham yang terdaftar di Bursa Efek Indonesia pada periode 2013-2016. Teknik pengambilan sampel yang digunakan adalah purposive sampling dengan kriteria sebagai berikut : a. Sampel harus memiliki tanggal aktif sebelum periode penelitian, yaitu Januari 2013 s/d desember 2016. b. Sampel yang dipilih harus aktif beroperasi selama periode penelitian yaitu januari 2013 sampai desember 2016. c. Sampel masih aktif mengelola dana dalam bentuk Reksa Dana Saham.

\section{Sumber Data dan Teknik Pengumpulan Data}

Data yang digunakan pada penelitian ini adalah Data Sekunder dimana metode pengumpulan datanya menggunakan metode dokumentasi dari berbagai literatur dan situs internet (www.infovesta.com, www.investing.com, www.bi.go.id, www.bps.go.id, www.kontan.co.id.

\section{Teknik Analisis Data}

Teknik analisis data yang digunakan dalam penelitian ini deskriptif kuantitatif. Data diolah sesuai dengan definisi operasional variable menggunakan bantuan program Microsoft Excel dengan langkah-langkah penghitungan sebagai berikut : 1. Mengukur Kinerja Reksa Dana a. Mengumpulkan data NAB bulanan masing-masing Reksa Dana saham yang dijadikan sampel selama periode pengukuran serta data pergerakan IHSG dan BI rate selama periode pengukuran. b. Menghitung risiko berdasarkan standar deviasi dan beta. Penulis melakukan analisis penghitungan menggunakan risk adjusted return dengan metode sharpe. Metode sharpe diperoleh dari return reksa dana dikurangi dengan BI rate. Hasil dari excess return tersebut kemudian dibandingkan dengan standart deviasi. c. Melakukan analisis perhitungan 
menggunakan metode Treynor. Perhitungan kinerja reksa dana ini merip dengan metode Sharpe yaitu dengan menghitung excess return yang diperoleh dengan return reksa dana dikurang BI rate. Hanya saja pembandingnya berupa beta yang merupakan tingkat risiko sistematik suatu perusahaan. d. Melakukan analisis penghitungan menggunakan risk-adjusted return dengan metode Jensen. Metode Jensen diturunkkan dan Capital Asset Pricing Model (CAPM). Langkah pertama adalah menghitung return reksa dana dengan mengurangkan NAB saat ini dengan NAB sebelumnya kemudian dibagi NAB sebelumnya. Kedua, return yang diperoleh dikurangi dengan BI rate yang kemudian ditambahkan dengan beta sebagai risiko sistematisnya.

Membandingkan hasil kinerja masing-masing reksa dana saham berdasarkan setiap metode yang digunakan dengan return bencmark (IHSG). Adapun kriteria yang digunakan adalah sebagai berikut : a. Jika kinerja reksa dana saham lebih besar dari kinerja benchmark, maka reksa dana tersebut tergolong pada kondisi yang outperform dan layak dipilih sebagai saran investasi. b. Jika kinerja reksa dana saham lebih kecil dari kinerja benchmark (IHSG), maka reksa dana tersebut tergolong pada kondisi yang underperform dan tidak layak dipilih sebagai sarana investasi.

\section{HASIL PENELITIAN DAN PEMBAHASAAN}

\section{Deskripsi Data Selama Periode Penelitian}

Penelitian ini menggunakan data NAB bulanan yang penutupannya setiap akhir bulan mulai dari januari 2013 sampai desember 2015. IHSG dan BI rate yang dipakai mulai dari bulan Januari 2013 sampai Desember 2015 sebagai data mentah. Kemudian data mentah (raw material) tersebut diolah dan dijelaskan secara deskriptif sehingga menghasilkan sebuah informasi yang dapat digunakan oleh para investor atau pihak terkait yang membutuhkan data tentang kinerja reksa dana saham. Adapun hasil deskripsi data selama periode penelitian dapat dilihat sebagai berikut :

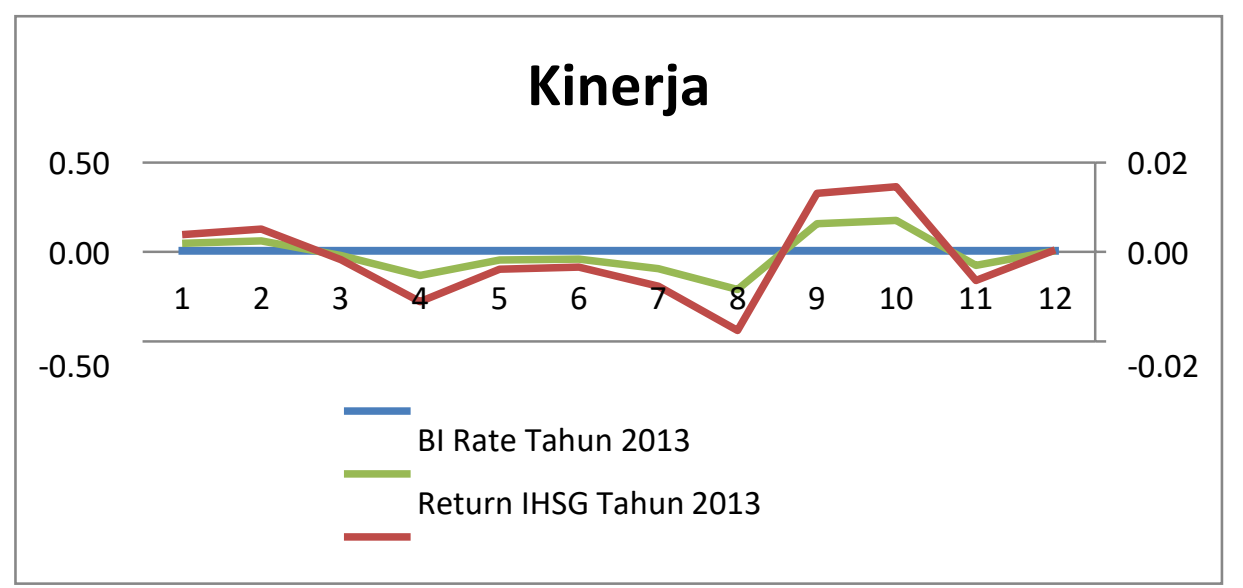

Gambar 1. Kinerja rata-rata 48 reksa dana saham, IHSG dan BI rate pada tahun 2013

Berdasarkan gambar 1 terlihat bahwa pada awal tahun 2013 hingga pertengahan bulan Agustus rata-rata kinerja 48 reksa dana saham berada di bawah kinerja BI rate. Sedangkan kinerja IHSG berada di atas BI rate hanya sampai awal bulan Maret. Mulai bulan Maret, kinerja IHSG mulai menunjukkan kinerja yang negatif sampai pertengahan bulan Agustus. Selanjutnya, pada awal bulan September kinerja 48 reksa dana saham dan IHSG berada diatas BI rate. Namun, mulai awal bulan Oktober kinerja rata-rat 48 reksa dan saham dan kinerja IHSG mulai mengalami penurunan yang cukup signifikan dan hingga 
akhir periode penelitian pada tahun 2013 kedua kinerja belum mampu melebihi kinerja BI rate. Secara garis besar pada tahun 2013 rata-rata kinerja 48 reksa dana saham berada di atas kinerja IHSG. Namun, belum mampu melebihi kinerja BI rate. Hal ini menunjukkan bahwa reksa dana saham belum layak dijadikan tempat investasi yang menguntungkan. Penyebab hasil buruk yang di dapat pada tahun 2013 yaitu Karena pada pertengahan sampai akhir tahun 2013 IHSG mengalami penurunan yang disebabkan perlambatan ekonomi global dan juga kebijakan stimulus dari Bank Sentral Amerika Serikat (The Fed) yang berdampak pada penurunan kinerja pasar modal di kawasan regional maupun global tak terkecuali Bursa Efek Indonesia (BEI). Kinerja pasar modal Indonesia jatuh 3,7\%. Menurut Muliaman D. Hadad dalam https://finance.detik.com/bursa-dan-valas/d2449810/kinerja-pasar-modal-indonesia-tahun-ini-anjlok menyebutkan, per 20 Desember 2013, Indeks Harga Saham Gabungan (IHSG) ditutup pada posisi 4.195,6 atau turun 3,47\% jika dibandingkan dengan posisi pada 2 Januari 2013.

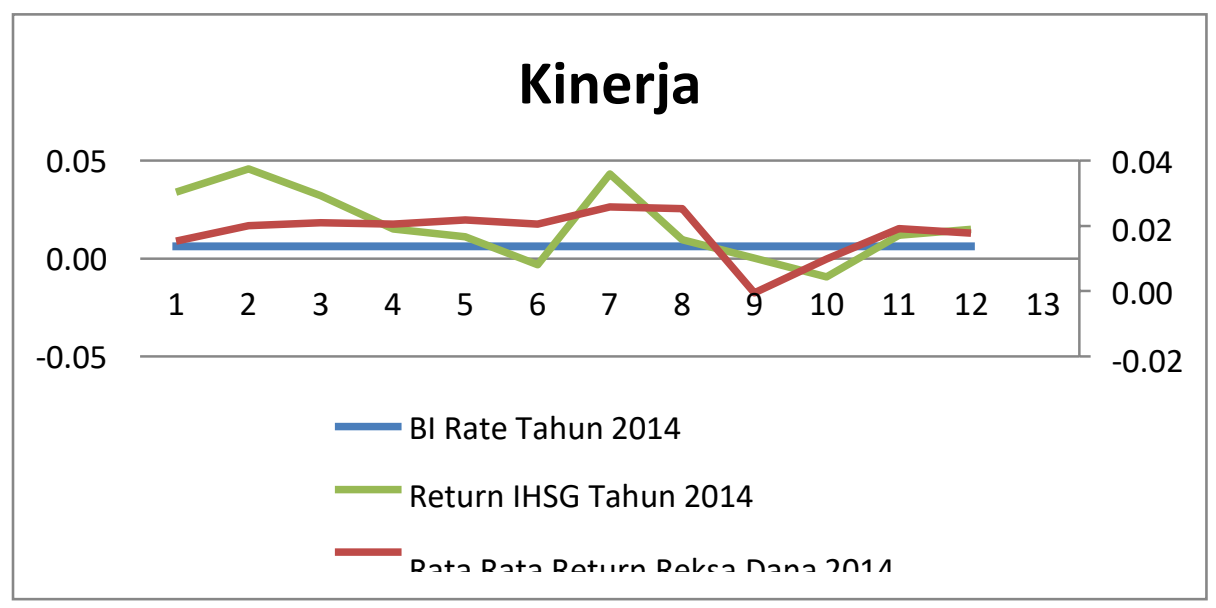

Gambar 2. Kinerja rata-rata 48 reksa dana saham, IHSG dan BI rate pada tahun 2014.

Berdasarkan gambar 2 dapat dilihat bahwa mulai dari awal tahun 2014 hingga akhir bulan Agustus 2014 kinerja rata-rata 52 Reksa Dana saham berada diats kinerja BI rate, dan kinerja IHSG mampu menunjukkan kinerja yang positif dan berada di atas kinerja BI rate tetapi hanya sampai akhir bulan Mei 2014. Namun, mulai awal bulan Juni kinerja IHSG menunjukkan peningkatan yang cukup signifikan dan kembali menunjukkan trend positif mulai pertengahan bulan Juni 2014 hingga awal bulan Agustus 2014. Meskipun kinerja ratarata 48 Reksa Dana saham dan kinerja IHSG sempat menunjukkan pertumbuhan negatif dan berada di bawah kinerja BI rate pada akhir bulan September dan awal bulan Oktober kinerja rata-rata 48 Reksa Dana saham terus mengalami pertumbuhan positif hingga akhir periode 2013. Secara garis besar pada tahun 2014 rata-rata kinerja 48 Reksa Dana saham dan kinerja IHSGmampu melebihi kinerja BI rate. Hal ini menunjukkan bahwa meskipun kinerja rata-rata 48 Reksa Dana saham mampu berada di atas kinerja BI rate, Reksa Dana saham layak dijadikan tempat investasi, tetapi masihperlu dipertimbangkan.

Hasil yang didapatkan pada tahun 2014 berbeda jauh dengan tahun2013, pada tahun 2014 IHSG mengalami peningkatan yang signifikan. Menurut Kepala Eksekutif Pengawas Pasar Modal Otoritas Jasa Keuangan (OJK) Nurhaida dalam konferensi pers penutupan perdagangan Bursa EfekIndonesia (BEI), di Gedung BEI, Jakarta, Selasa (30/12/2014). https://finance.detik.com/bursa-dan-valas/d-2790227/ihsgtumbuh-2115-di-2014-tertinggi-keempat-di-dunia, "pengaruh suhu politik akibat pelaksanaan 
Pemilihan Umum (Pemilu) di Juli 2014 tidak menyurutkan optimisme investor untuk tetap bertransaksi di pasar modal Indonesia. Hal ini dibuktikan dengan pergerakan IHSG yang mengalami kenaikan 21,15\% yaitu dari 4.274,177 pada akhir 2013 menjadi 5.178,373 pada 29 Desember 2014. Bahkan, pada 8 September 2014, IHSG telah berhasil mencatatkan rekor indeks tertinggi sepanjang sejarah dengan ditutup pada level 5.246,489. Peningkatan persentase level IHSG hanya di bawah Bursa Shanghai dengan kenaikan 49,72\%, Bursa India 28,52\%, danPhilipina 22,76\%. Level IHSG di sepanjang 2014 telah melebihi Bursa Thailand sebesar 15,15\%, Indeks Nikkei Jepang 8,83\%, Bursa Singapura 6,32\%, Bursa Hongkong 2\%, Bursa Australia 1,75\%, Indeks Indeks FTSE 100 Inggris -1,71\%, Bursa Korea -4,15\%, Indeks Dow Jones Amerika Serikat -4,95\%, dan Bursa Malaysia -5,28\%

Faktor internal yang mempengaruhi berkembangnya IHSG pada tahun 2014 yaitu adanya perbaikan defisit transaksi berjalan atau current account deficit (CAD) yang ditargetkan sampai akhir tahun di bawah 3\%. Di samping itu juga pengendalian inflasi sebesar $4,5 \%$. Selain faktor internal, IHSG juga dipengaruhi oleh beberapa faktor eksternal. Pertama adalah faktor dari perkembangan ekonomi dari Amerika Serikat (AS).Kedua, adalah pertumbuhan ekonomi Jepang yang membaik di triwulan I- 2014.

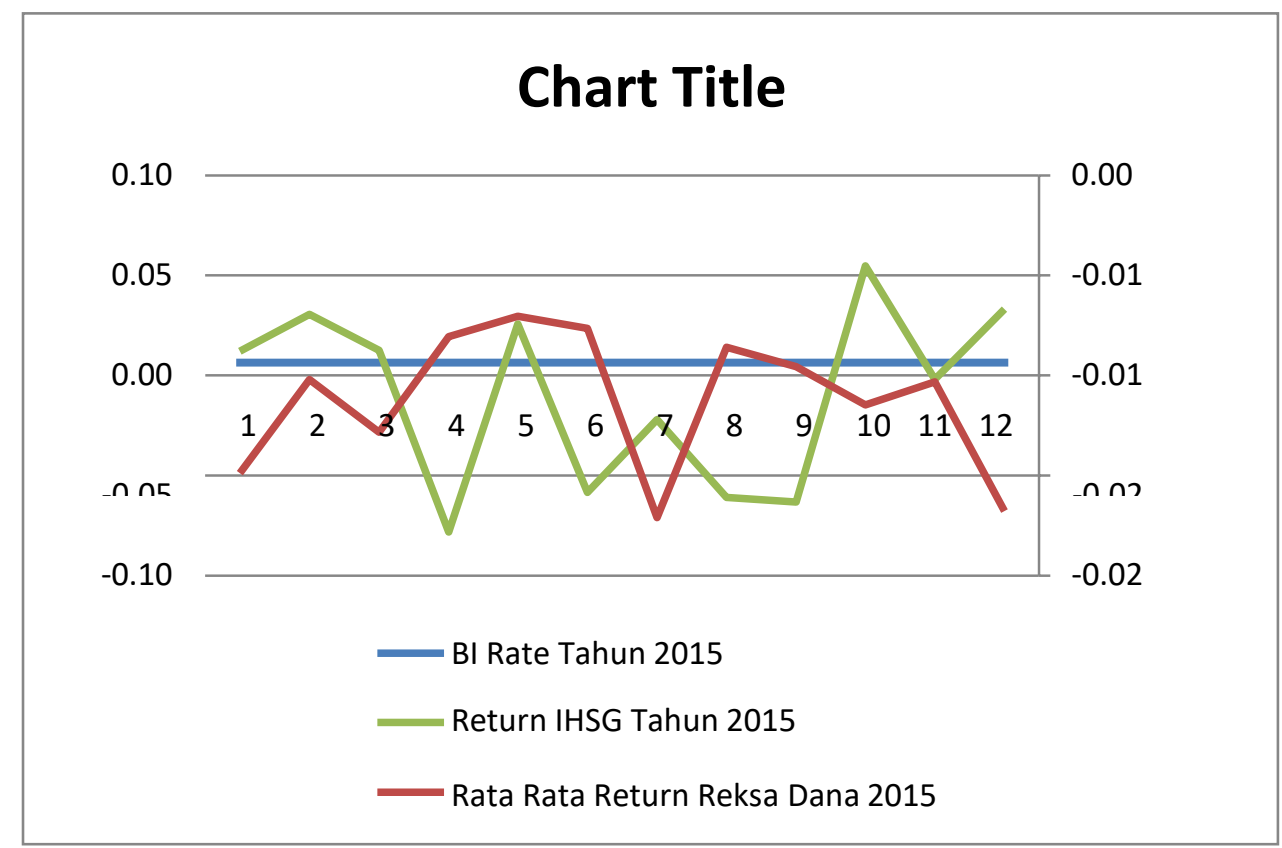

Gambar 3. Kinerja rata-rata 48 reksa dana saham, IHSG dan BI rate pada tahun2015

Berdasarkan informasi pada gambar 4.3 pada awal 2015 sampai dengan bulan Maret akhir. Kinerja IHSG dan 48 reksa dana saham mengalami penurunan. Bahkan penurunan terburuk terjadi pada awal bulan Maret sampai awal bulan Juni 2015 untuk kinerja IHSG. Akan tetapi kinerja 48 reksa dana saham mengalami kenaikan di awal bulan Maret sampai bulan Mei akhir dan keduanya kembali mengalami penurunan yangsignifikan pada awal bulan Juni. Namun, mulai awal bulan Agustus kedua kinerja menunjukkan kenaikan yang cukup signifikan dan kembali menunjukkan trend positif mulai pertengahan bulan September 2015. Meskipun kinerja rata-rata 48 Reksa Dana saham sempat menunjukkan pertumbuhan positif dan berada di atas kinerja BI rate pada awal bulan Agustus dan awal bulan September kinerja rata-rata 48 Reksa Dana saham terus mengalami pertumbuhan negatif hingga akhir periode 2015 . Hal ini menunjukkan bahwa Reksa Dana saham merupakan investasi yang menguntungkan pada awal periode bulan Maret hingga akhir bulan Mei 2015. Namun, Reksa Dana saham belum layak dijadikan tempat investasi yang menguntungkan karena kinerja 48 reksa dana saham rata-rata 
salalu dibawah kinerja BI rate mulai awal tahun hingga akhir periode meskipun kinerja ratarata Reksa Dana saham selalu berada di atas kinerja IHSG.

Sepanjang Januari hingga Desember 2015, IHSG mengalami tren konsolidasi. Kenaikan suku bunga bank sentral Amerika Serikat (AS) membuat investor asing mengalihkan sebagian dananya keluar dari instrumen portofolio di Indonesia yang ditandai dengan nilai jual bersih (net selling) dana investor asing di pasar modal domestik sebesar Rp22,58 triliun. Menurut data Bursa Efek Indonesia (BEI), dampak darikondisi global tersebut turut menyebabkan Indeks Harga Saham Gabungan (IHSG) per 30 -Desember 2015 ditutup di level 4.593 poin atau mengalami penurunan sebesar $12,13 \%$, dibandingkan penutupan akhir Desember 2014 yang berada di level 5.226 poin. Nilai kapitalisasi pasar saham pun ikut berubah turun 7,54\% dari Rp 5.228 triliun padaakhir Desember 2014 menjadi Rp 4.873 triliun per 30 Desember 2015.

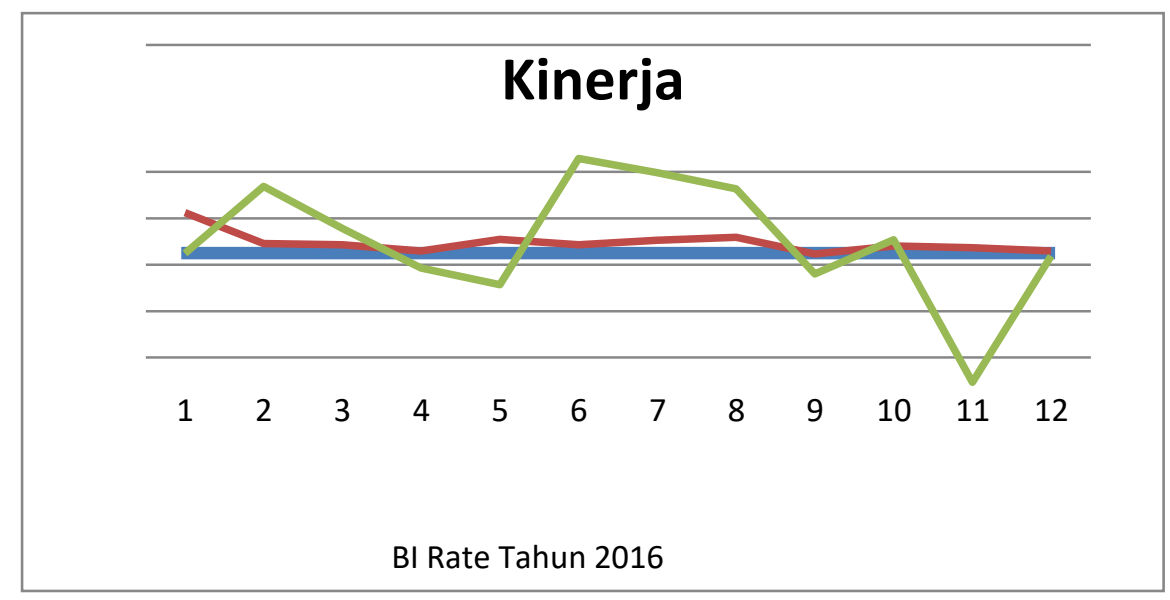

\section{Gambar 4. Kinerja rata-rata 48 reksa dana saham, IHSG dan BI rate pada tahun 2016}

Berdasarkan gambar 4.4 dapat dilihat bahwa mulai dari awal tahun 2016 hingga akhir bulan Desember 2016 kinerja rata-rata 48 Reksa Dana saham berada diatas kinerja BI rate, dan kinerja IHSG mampu menunjukkan kinerja yang positif dan berada di atas kinerja BI rate Pada awal bulan tetapi hanya sampai pertengahan bulan Maret 2016 dan IHSG mengalami penurunan pada bulan Mei. Namun, mulai awal bulan Juni kinerja IHSG menunjukkan peningkatan yang cukup signifikan sampai bulan Agustus dan kembali menunjukkan trend negatif mulai awal bulan Oktober 2016 hingga akhir bulan Desember 2016. Secara garis besar pada tahun 2016 rata-rata kinerja 48 Reksa Dana saham dan kinerja IHSG mampu melebihi kinerja BI rate. Hal ini menunjukkan bahwa kinerja rata- rata 48 Reksa Dana saham mampu berada di atas kinerja BI rate, investasi pada Reksa Dana saham masih perlu dipertimbangkan.

Perdagangan akhir tahun 2016, Indeks Harga Saham Gabungan (IHSG) ditutup di level 5.296, atau naik 15,32\% dibandingkan penutupan perdagangan tahun 2015. Pengamat ekonomi Sumut Gunawan Benjamin dalam http://medan.tribunnews.com/2016/12/30/kinerja-ihsg-sepanjang-2016-mengalami penguatan mengatakan, Bahwa banyak Faktor_pemicu tekanan yang begitu kuat yang terjadi di bursa selama tahun 2016, katanya, banyak dipicu oleh sentimen eksternal. "Beberapa di antaranya adalah potensi munculnya krisis perbankan di Jerman yang dipicu oleh Deutsche Bank, Kemenangan Donald Trump, dan keputusan menaikkan suku bunga acuan oleh Bank Sentral AS atau The FED," katanya Jumat (30/12/2016). Sementara itu, dijelaskannya, demonstrasi yang menggerakkan banyak massa di Indonesia awalnya memberikan kekhawatiran. Namun, justru berbuah manis saat aksi damai telah berlangsung.

\section{KESIMPULAN DAN SARAN}




\section{Kesimpulan}

Penelitian ini bertujuan untuk mengetahui kinerja Reksa Dana saham menggunakan metode Sharpe, Treynor, Jensen serta mengetahui perbandingan antara kinerja Reksa Dana saham dengan kinerja benchmark (IHSG) pada tahun 2013, 2014, 2015 dan 2016. Data yang diperoleh kemudian diolah dan dianalisis secara deskriptif kuantitatif. Berdasarkan penelitian yang dilakukan, hasil analisis menunjukkan : 1. Kinerja Reksa Dana Saham dengan Metode Sharpe. Berdasarkan metode Sharpe pada tahun 2013, terdapat 4 Reksa Dana saham yang memiliki kinerja positif dan 44 Reksa Dana saham memiliki kinerja negatif. Pada tahun 2014, 47 Reksa Saham memiliki kinerja positif dan hanya 1 Reksa Dana saham yang memiliki kinerja negatif. Pada tahun 2015, tidak ada Reksa Dana satupun yang memiliki kinerja positif dan 48 Reksa Dana saham memiliki kinerja yang negatif. Sedangkan untuk tahun 2016, 48 reksa dana saham memiliki kinerja positif dan tidak ada reksa dana yang berkinerja negatif. Reksa dana dengan hasil yang positif menunjukkan bahwa return yang dihasilkan melebihi retrun bebas risiko Perbandingan kinerja reksa dana saham terhadapa benchmark dengan menggunakan metode sharpe mendapatkan hasil yang beragam. Pada tahun 2013 sebanyak 7 reksa dana saham memiliki kinerja outperform dan sebanyak 41 reksa dana saham underperform. Tahun 2014, 42 reksa dana saham outperform dan 6 reksa dana lainnya memiliki kinerja underperform. Kemudian di Tahun 2015 kinerja reksa dana saham mengalami penurunan, terbukti dengan hasil data yang diperoleh hanya ada 1 reksa dana yang memiliki kinerja outperform dan 47 reksa dana saham underperform. Pada Tahun 2016 hasil kembali menunjukkan yang baik dengan bukti bahwa hanya ada 8 reksa dana saham yang underperform dan 38 reksa dana saham lainnya mampu outperform terhadapat bencmark IHSG. Reksa dana saham terbaik pada tahun 2013 berdasarkan metode sharpe adalah First state indoequity hight conviction fund dengan nilai sharpe sebesar 0,08066 dan berstatus outperform. Kemudian pada tahun 2014, reksa dana saham dengan kinerja terbaik adalah Danareksa Mawar dengan nilai sharpe 6,1575 dan berstatus outperform. Kemudian pada tahun 2015 reksa dana saham yang memiliki kinerja terbaik yaitu Schoder Dana Prestasi Plus dengan nilai -0,12896 dan berstatus outperform. Pada tahun 2016 reksa dana terbaik adalah Panin Dana Prima dengan hasil 28.34923 dan mampu outperform.

Kinerja Reksa Dana Saham dengan Metode Treynor. Berdasarkan metode Treynor pada tahun 2013 terdapat 44 Reksa Dana saham dengan kinerja positif dan 4 Reksa Dana saham dengan kinerja negatif. Pada tahun 2014, terdapat 47 Reksa Dana saham yang memiliki kinerja positif dan hanya 1 Reksa Dana saham yang memiliki kinerja negatif. Sedangkan pada tahun 2015, tidak ada reksa dana saham yang memiliki kinerja yang positif, 48 Reksa Dana lainnya memiliki kinerja negatif. Pada tahun 2016 terdapat 37 reksa dana saham yang mempunyai kinerja positif dan hanya ada 11 reksa danayang mempunyai hasil negatif. Reksa Dana dengan hasil yang positif menunjukkan bahwa return yang dihasilkan melebihi return investasi bebas risiko. Kemudian perbandingan kinerja reksa dana saham terhadap benchmark dengan menggunakan metode Treynor mendapatkan hasil yang lebih baik. Pada tahun 2013 sebanyak 44 reksa dana saham memiliki kinerja outperform dan hanya 4 reksa dana saham yang memiliki kinerja underperform. Artinya mayoritas reksa dana saham memiliki kinerja yang baik. Tahun 2014 hanya 43 reksa dana saham yang memiliki kinerja outperform dan sebanyak 5 reksa dana lainnya memiliki kinerja underperform. Kemudian di tahun 2015 kinerja reksa dana saham mengalami penurunan yang signifikan, terbukti dengan hasil data yang diperoleh tidak ada reksa dana yang memiliki kinerja outperform dan 48 reksa dana saham underperform. Pada tahun 2016 reksa dana kembali menunjukkan hasil yang baik terbukti dengan 25 reksa dana saham yang mampu outperform terhadapat bencmark IHSG dan 23 lainnya memiliki kinerja underperform. Reksa dana saham terbaik pada tahun 2013 berdasarkan metode Treynor adalah reksa dana danareksa mawar komoditas dengan nilai sebesar 24,96478 dan berstatus 
outperform. Kemudian pada tahun 2014, reksa dana saham dengan kinerja terbaik adalah Reksa dana aberdeen indonesia equity fund dengan nilai 5,75289 dan berstatus outperform. Kemudian pada tahun 2015 reksa dana saham yang memiliki kinerja terbaik yaitu Scoder Dana Prestasi Plus dengan nilai -0,19734 dan berstatus outperform. Pada tahun 2016 reksa dana terbaik adalah Jisawi Progresif dengan nilai sebesar 3.65862 dan berstatus outperform.

\section{Saran}

Berdasarkan kesimpulan yang telah dipaparkan sebelumnya maka disampaikan beberapa saran sebagai berikut : 1. Bagi Investor Investor sebaiknya memilih Reksa Dana saham dengan kinerja positif dan memiliki status outperform terhadap kinerja benchmark ke dalam portofolio investasi mereka. Dalam penelitian ini investor sebaiknya menggunakan Metode Treynor terbukti dengan hasil yang di dapat pada tahun 2013 sebanyak 10444 Reksa Dana Saham mampu berkinerja positif dan 47 Reksa Dana Saham berstatus outperform terhadap kinerja benchmark. Untuk tahun 2014, 47 Reksa Dana Saham mampu menunjukkan hasil positif dan 43 Reksa Dana Saham berstatus outperform terhadap kinerja benchmark. Pada tahun 2015 Metode Treynor mengalami hasil yang buruk terbukti dengan hasil tidak ada Reksa dana yang mempunyai kinerja positif dan tidak ada yang mampu berkinerja positif, akan tetapi pada tahun 2016 Metode Treynor kembali menunjukkan hasil yang baik dengan bukti 48 reksa dan saham mampu berkinerja positif dan 40 reksa dana saham yang mampu berkinerja outperform terhadap benchmark IHSG.

\section{DAFTAR PUSTAKA}

Adi, Datu Pinastiko. (2014). Ananlisis Pengukuran Kinerja Reksa Dana Saham dengan Metode Risk Adjusted Return di Bursa Efek Indonesia Periode Tahun 2011-2013. Jurnal Manajemen. (Juli 2014).

Ang, Robert. (1997). Buku Pintar Pasar Modal Indonesia. Jakarta: Salemba Empat.

Brigham dan Houston. (2012). Dasar-DasarManajemen Keuangan. Jakarta : Salemba Empat.

Halim, Abdul. (2001). Analisis Investasi Edisi 2. Jakarta: Salemba Empat.

Hermeindito, Kaaro. (2007). Analisis Kinerja Reksa Dana Saham di Indonesia. Jurnal Manajemen dan Bisnis, Vol. 6 no 2 (sept 2007) page 138-148

Jogiyanto, Hartono. (2013). Teori Portofolio dan Analisis Investasi. Yogyakarta: BPFE UGM.

Jones. Charles P. (2002) Investment: Analysis and Management, 10th ed. New York: Jon Willy and Sons

Juwita \& Trisnadi. (2012). Analisis Kinerja Reksa Dana Saham Menggunakan Metode sharpe dan jensen. Jurnal Management dan Organisasi, Vol II, No.2 Agustus 2011.

Kuncoro, Mudrajad. (2007). Metode Kuantitatif, Teori dan Aplikasi untuk Bisnis dan Ekonomi, Yogyakarta: UPP STIM YKPN

Magdalena \& Amalia. (2012). Penelaian Kinerja Produk Reksadana dengan Menggunakan Metode Perhitungan Jensen Alpha, Sharpe Ratio, Treynor Ratio, M2, dan Informatio Ratio. Jurnal Manajemen, Vol.12, No.1, November 2012.

Manurung, Adler Haymans. (2008). Reksa Dana Investasiku. Jakarta: Penerbit Buku Kompas

Nurjanah, Nita. (2016). Ananlisis Pengukuran Kinerja Reksa Dana Saham dengan Metode Sharpe, Jensen,Treynor, M-square dan Information Ratio di Bursa Efek. Jurnal Manajemen. ( Juni 2014).

Pujiarti, Triswi dan Dewi, Frida Ratna. (2011). Analisis Kinerja reksa Dana Saham dengan menggunakan metode Sharpe dan Jensen untuk Periode 2005-2009. Jurnal Manajemen dan Organisasi, Vol.2, No.2, Agustus 2011 